\title{
ANTICIPATION OF BANK FAILURES IN THE REPUBLIC OF MOLDOVA
}

\section{Ciobu Stela}

Academy of Economic Studies, Chisinau, Republic of Moldova

\section{Iordachi Victoria}

National Institute for Economic Research, Chisinau, Republic of Moldova

\section{Jalba Andrei}

National Bank of Moldova, Chisinau, Republic of Moldova

\section{OMESTE}

JEL category: E5, E58, G21, G33

\begin{abstract}
The excessive risks taken by the banks resulted in banking crises, that caused the collapse of large financial institutions and even global recession. The main scope of this paper is to identify the causes, consequences, and methods of anticipating bank failures at national and international levels. The proposed scope is materialized in the following research task: identifying the ability of the National Bank of Moldova (NBM) to influence the local banks, as well as analyzing the legal framework regarding bank recovery and resolution. The research theme results from the necessity to maintain a stable and reliable banking system in order to ensure the continuity of financial intermediation, protect the depositors' interests and contribute to the development of a strong economy. The value of the investigation is determined by the practical relevance of the study carried out, as well as by the recommendations contained in the paper, the implementation of which will contribute to streamlining the prudential supervision of the domestic banking system, preventing bank failures in future and ensuring the financial stability of the banking system in the Republic Moldova.
\end{abstract}

Keywords: banks, financial stability, bank supervision, central bank, bank failure, prudential regulation.

\section{INTRODUCTION}

The main causes of the financial crises from 2008 were the excessive risk taken by the financial institutions, especially banks, combined with poor corporate governance and imperfect regulations. The excessive risk taken by the banks resulted in banking crises, that caused the collapse of large

Address of the corresponding author:

Stela Ciobu

stela.ciobu@gmail.com financial institutions, impressive government spending for preventing banks' closure, a decline in business activity and in consumer spending, leading the path to a global recession. The impact and the cost of the banking crisis were considerable and therefore maintaining a stable banking system became one of the key elements in achieving sustainable economic development. The recent global financial crisis, as well as the local banking crisis from 2014-2015, proved that anticipation of bank failures is still an important 
and actual topic, with the legal and regulatory framework still being imperfect and behind the events and the new risks to which the banking system is exposed in the 21 st century.

Moreover, the actuality of the research theme results from the necessity to maintain a stable and reliable banking system in order to ensure the continuity of financial intermediation, protect the depositors' interests and contribute to the development of a strong economy. Furthermore, the necessity to identify the effective methods of preventing and anticipating crises and bank failures remains one of the topics that still have to be researched and developed.

The effects of the global financial crisis as well as of the banking crisis in the Republic of Moldova are still felt. Because of these shocks, the authorities have made considerable efforts in reviewing and improving the regulatory and legal frameworks to promote the stability of the financial and banking system. For this purpose, the new regulatory framework, based on Basel III requirements, was introduced, and a new Law on bank recovery and resolution was adopted.

The main scope of this paper is to identify the causes, consequences, and methods of anticipating bank failures, both nationally and internationally. The proposed scope is materialized in the following research task: identifying the ability of the National Bank of Moldova (NBM) to influence the local banks, as well as analyzing the legal framework regarding bank recovery and resolution.

The informational support of the research consists of the reports and publications of the international financial institutions (the International Monetary Fund, the Bank for International Settlements, the World Bank, the Basel Committee on Banking Supervision), the normative acts, the publications and the statistical data on the official website of the National Bank of Moldova, publications on the research theme of central banks in European countries, results of scientific researches published in the Republic of Moldova, Romania and other countries, presentations included in international conferences, etc.

The value of the investigation is determined by the theoretical competence and the practical relevance of the study carried out, as well as by the recommendations contained in the paper, the implementation of which will contribute to streamlining the prudential supervision of the domestic banking system, preventing bank failures and ensuring the financial stability of the banking system in the Republic Moldova.

\section{EVALUATING THE CREDIBILITY AND TRUSTABILITY OF THE CLIENTS FROM THE BANKING SECTOR OF THE REPUBLIC OF MOLDOVA}

The National Bank of Moldova is the central bank of the Republic of Moldova and exercises its attributions as a legal, public and autonomous entity that is responsible to the Parliament. The fundamental objective of the National Bank is the maintenance and insurance of prices stability.

The National Bank is independent in exercising its attributions established by the Law on the National Bank of Moldova and neither requires nor receives, according to the same law, instructions from public authorities or from any other authority. The NBM is responsible for licensing, supervision and regulation of banks' activities. As from 2018, the banking activity is carried out in compliance with Basel III requirements, which is going to be implemented by stages till 2020 .

In order to achieve its attributions, the National Bank has the right to issue decisions, regulations, instructions, and orders. The normative acts of the National Bank, which are compulsory for financial institutions and other legal and natural persons are published in the Official Monitor of the Republic of Moldova and come into force either on the date of their publication, or on another date stipulated in the text of the respective normative act, provided that the public is informed accordingly.

The role of the NBM in maintaining financial stability is of major importance, as a result of the significant share held by the banking sector in the financial system. Within the NBM, the tasks related to financial stability are carried out through issued regulations and performed prudential supervision, through the efficient transmission of monetary and foreign exchange policy measures and through the supervision of the payment system's functioning. The financial stability monitoring is based on identifying risks and vulnerabilities both at an individual and systemwide level in order to determine the systemic 
impact of the institutions that are under the central bank' supervision. Based on the Decree of the Government of the Republic of Moldova no. 449 as of June 2, 2010, the National Committee for Financial Stability (NCFS) was created. The National Bank of Moldova (NBM) is part of the nominal composition of the NCFS and the Governor of the NBM is the Vice President of the Committee. Following the creation of the NCFS, the duties of committee members have been established based on the Memorandum of understanding on the maintenance of financial stability from February 28, 2011. According to its provisions, the NBM is one of the key institutions responsible for maintaining the financial stability of the banking sector and the supervised financial institutions through available legal powers (NBM, 2011).

Regarding measures that can be taken at a microeconomic degree, initially, at the level of the national legislative framework, provisions regarding the measures that may be ordered by the National Bank for the recovery of the situation of a commercial bank in difficulty were mainly found in the Law on Financial Institutions. The special procedures provided for it consisted of a series of measures, namely: special supervision, special administration, remedial measures or forced liquidation.

Under Chapter $\mathrm{V}^{1}$ of the Law on Financial Institutions no. 550-XIII of 21.07.1995, Official Monitor of R. Moldova no. $78-81 / 199$ of 13.05.2011 (chapter repealed by Law no. 233 of 03.10.2016, Official Monitor of R. Moldova no. 343-346 of 04.10.2016), the National Bank of Moldova may establish special supervision over a bank if it finds the financial situation of the bank or if it finds that the bank (financial institution) or any of its shareholders or administrators have violated this Law, the regulations of the National Bank, the conditions for issuance of license or the requirements provided by the authorization, permission, approval, confirmation, the breach of the fiduciary obligations, the obligations under the legislation on the prevention and combating money laundering and terrorism financing, the observance of which falls under the powers of the National Bank, or if the bank (financial institution) jeopardizes the interests of depositors, failed to report or reported with delay, reported erroneous data on banking prudential indicators or other requirements provided in the regulations of the National Bank or failed to comply with remedial measures established by the National Bank.

The special supervision is carried out by a commission created for this purpose, consisting of up to 5 employees of the National Bank, one of whom shall act as the chairman of the commission and one as a deputy chairman. Thus, special supervision commission shall not affect the duties and powers of the National Bank to apply, before or during the special supervision, other measures, and sanctions provided by the Law, including the establishment of special administration or license withdrawal and forced liquidation.

According to Article $37^{2}$ of Law on Financial Institutions (1996), the main duties of the special supervision commission consist of:

1. analysis of the bank's financial situation;

2. verifying the existence of the grounds referred to in Article 374 paragraph (2) and Article 38 paragraph (3);

3. monitoring the way, the bank's Board, executive body and administrators act to establish and apply the measures necessary to remedy the violations and deficiencies or, where appropriate, the recommendations of the commission or measures imposed by the National Bank in accordance with this Law;

4. formulating recommendations to the bank on:

a. suspension or repeal of certain decisions of the bank's management bodies, which are contrary to the requirements of prudence or lead to the deterioration of its financial situation;

b. amending/supplementing the bank management framework, strategies, processes, and mechanisms implemented by the bank;

c. limitation and/or suspension of some activities and operations of the bank for a certain period;

d. any other measures deemed necessary to remedy the violations and/or situation of the bank;

5. formulation of recommendations to the National Bank on the implementation of certain measures or application of sanctions provided by law if the bank's Board, executive body or administrators do not comply with the 
measures recommended by the commission, it has not produced the expected result.

It is to be mentioned that the special supervision commission does not replace the bank administrators regarding the current management of the activity and the competence to undertake commitments on behalf of the bank. Responsibility for the legality, validity, accuracy, and timeliness of the operations and documents of the bank lies exclusively with the bank administrators and/or persons who prepare and sign such documents, according to their duties and competencies. Also, the members of the special supervision commission should have access to all information, documents, and records of the bank and shall be obliged to keep professional secrecy of its operations. During supervision, the bank management bodies, employees and other persons shall not hinder the members of the special supervision commission in fulfilling their duties.

The special supervision commission submits periodically to the National Bank reports and recommendations about the bank. The recommendations should include proposals on the most rapid and cost-efficient way to remedy the violations and deficiencies and should provide recommendations for the minimization of the risk for bank depositors and other creditors of the bank, as well as for financial stability. Depending on the proposals and conclusions contained in the reports of special supervision commission, the National Bank should decide on the termination or continuation of special supervision for a period not exceeding 3 months from the date of its establishment.

If serious deficiencies are still found within the bank activities, the National Bank may decide, depending on the case, whether to apply the special administrative measures to the bank or other measures provided by the law, including the withdrawal of bank license and its forced liquidation.

According to Article $37^{4}$ of Law on Financial Institutions (repealed), special administration represents an administration regime established for a certain period over a bank, which means the implementation of a set of administrative, financial, legal, and organizational measures in order to create the optimal conditions for preserving the value of assets, eliminating the deficiencies in the administration of the bank and in administration of its patrimony, collecting the debts, determining the possibilities to remedy the financial situation, including restructuring or liquidation of the bank.

The National Bank may establish special administration over a bank if:

a. the establishment of special supervision did not give any results;

b. the amount of bank's capital is below the amount of regulatory capital set forth in the regulations of the National Bank, or it's capital adequacy ratio is by at least $1 / 3$ below the ratio established by the respective regulations;

c. the bank liquidity ratio is by at least $1 / 4$ below the ratio set forth in the regulations of the National Bank;

d. the bank fails to comply or is unable to comply with the remedies imposed by the National Bank;

e. the bank systematically hinders the exercising of banking supervision duties by concealing accounts, assets, registers, reports, documents, and information or by unreasoned refusal to submit them to the authorized persons of the National Bank;

f. the bank's management bodies are not able to ensure the compliance of bank's activity with the legislation, particularly in relation to conflicts that disrupt the bank's activity, arrest or suspension from office of the administrators due to a criminal case or their conviction for the committed crime;

g. this is requested by the bank on the basis of the decision taken by the Board or general meeting of shareholders of the bank.

The special administration shall be established for a period of up to 9 months. The term of special administration may be extended only once for a period not exceeding 3 months. The decision on establishing/extending the period of special administration shall contain the grounds of establishing/extending the period, as well as the period of special administration, data about the special administrator and, where appropriate, the restrictions or conditions on the activity of the bank. The bank shall be immediately notified in writing on such a decision. 
Special administration shall be carried out by a special administrator appointed by the decision of the National Bank on the establishment of special administration. In exercising its duties and rights, the special administrator shall be responsible solely to the National Bank, which has the authority to give instructions and recommendations related to its activities. In exercising its duties and rights, the special administrator shall give high priority to the interests of depositors and other creditors that are not affiliated to the bank as opposed to the shareholders and creditors that are affiliated to the bank. The bank and its shareholders shall not make the special administrator or the National Bank responsible for the damages caused in connection with the actions undertaken during the special administration if these actions have been undertaken for the purpose of non-admission of excessive risk to financial stability, to protect the interests of depositors and other creditors of the bank.

However, the banking crisis of the last period resulted in the granting of emergency loans of over 13 billion MDL under the Government's guarantee and liquidation of three banks has demonstrated the inefficiency and shortcomings of the regulatory framework. The financial crisis has also shown that there is a significant lack of adequate tools at the central bank level for the efficient and rapid management of the situation of banks in difficulty, which has proved to have a significant impact on the destabilization of the entire financial and banking sector. Under these circumstances, it was essential to approve a new strong legal framework, linked to the best international practice, which could prevent future crises and contain enough range of instruments that could be used.

Taking into account that Chapter V1 of the Law on financial institutions which describes the procedures that can be taken by National Bank under special supervision and special administration was repealed by Law no. 233 of 03.10.2016, Official Monitor of R. Moldova no. 343-346 of 04.10.2016), development of a new legal, institutional and regulatory framework on financial stability was one of the main actions aimed at strengthening and reforming the financial and banking sector in the Republic of Moldova. That's why the new Law on bank recovery and resolution no. 232 of 03.10.2016 (Official Monitor of R. Moldova no. 343-346 art. 707 of 04.10.2016) was approved. In its drafting, was considered the experience of the EU Member States and the provisions of Directive 2014/59/EU of the European Parliament and of the Council establishing a framework for the recovery and resolution of credit institutions and investment firms. This was a fundamental reform of the regulation and supervision of financial markets, which establishes a regime that ensures that the authorities effectively coordinate their actions and have appropriate rapid intervention tools to manage the difficulties faced by credit institutions and other financial institutions.

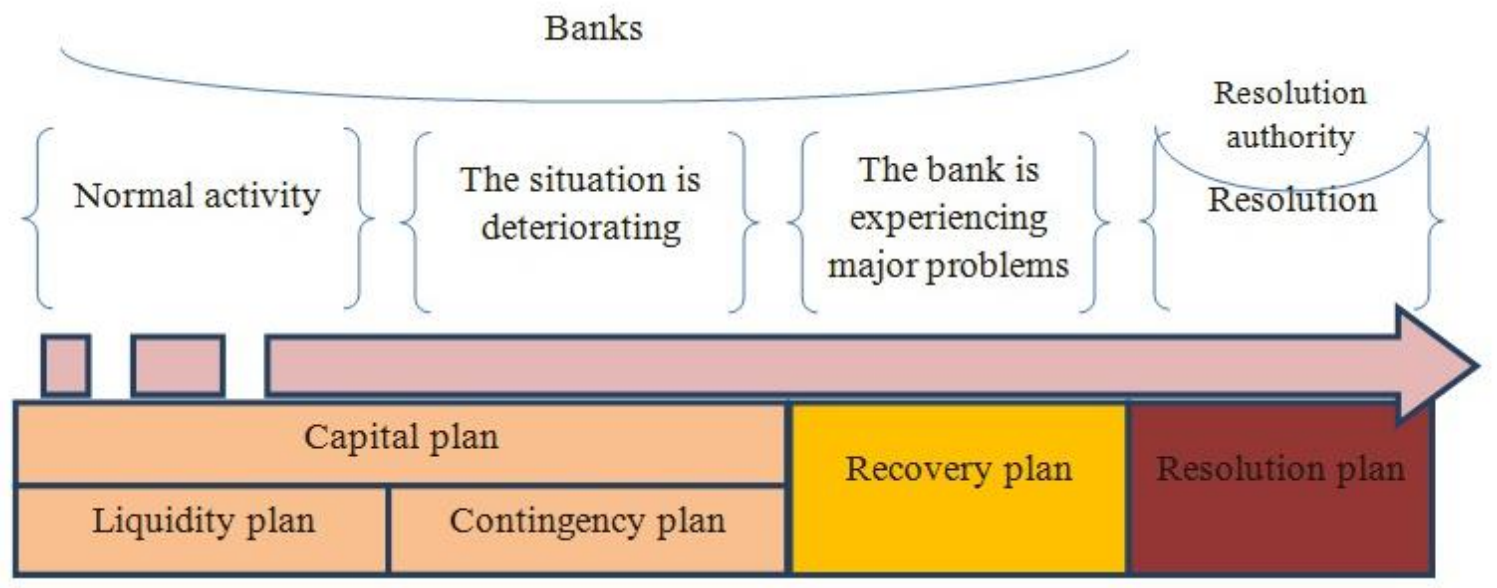

Fig. 1 Recovery plan vs. resolution plan

Source: Author

The new Law on bank recovery and resolution represents a new state intervention instrument, harmonized with the EU Directive, and considered necessary to prevent the bankruptcy of a banking institution. Also, if bankruptcy becomes inevitable, the law seeks to minimize negative consequences 
in terms of maintaining the systemic functions of the bank by making it viable if possible, or, if appropriate, by transferring these functions to another entity. The term "banking resolution" in the context of the Law describes the process of restructuring a banking institution by the resolution authority, using resolution tools and competencies to ensure the continuity of the core functions of that institution (e.g. deposits), the restoration of its viability, in whole or in part, and the liquidation of its residual part. Figure 1 presents the timeline of actions to be taken under the new legal framework. Accordingly, the framework for crisis management in the financial and banking sector according to the law is structured on three pillars:

- preparation,

- early intervention,

- banking resolution.

For each pillar, the Law sets trigger conditions, the authorities involved, the competencies and tools that can be applied, and the ways of implementing them. At the same time, the Law also describes the way in which the resolution is financed, the exemptions from the application of other normative acts, the security mechanisms, the remedies available to those who consider themselves prejudiced.

\subsection{PREPARATION}

The first step in case of a need to recover the situation of a bank or the application of a resolution instrument is achieved by the bank's elaboration of a recovery plan on the one hand and the elaboration by the NBM of a resolution plan on the other hand. Thus, according to art. 9 of the Law on bank recovery and resolution, each bank develops and maintains a recovery plan which provides measures to be taken by it to restore its financial position in the event of its significant deterioration. The Recovery Plan is a risk management tool aimed at determining the procedures for early identification of financial vulnerabilities and measures to mitigate the negative impact of a possible crisis situation as well as a subsequent recovery of the bank's financial situation. It is intended to ensure the bank's operational and business continuity and minimize financial losses caused by unexpected events that may arise from disturbances in payment and settlement systems in the event of a serious interruption of activity. In a crisis situation, it must reflect that the most appropriate alternative recovery option identified in the Recovery Plan will be implemented. Selecting recovery options requires a case-bycase analysis of potential stress situations by the management of the institution. Recovery options should reflect the institution's individual profile and analyze the internal preconditions and externalities of the recovery options.

Under the Law on bank recovery and resolution no. 232 of 03.10 .2016 , the recovery plans should include the following:

a. the information provided in Section $A$ of the Annex of the Law, as well as other information, according to the regulations issued by the National Bank of Moldova;

b. measures that can be taken by the bank when the conditions for early intervention are met;

c. adequate conditions and procedures to ensure that timely recovery measures are implemented, as well as a wide range of recovery options.

In the case of banks with a non-significant systemic impact on the banking sector, the plans may contain simplified requirements. When developing such plans, both the commercial bank and the central bank will focus on close cooperation, having as their primary objective the least impact on the country's financial system and on the resources of the public budget.

Therefore, the key components of the Recovery Plan are:

a. The description of internal governance that should allow adequate planning, approval, and implementation of the planning process within the institution, on the one hand, and enable decision-making in good time and the implementation of recovery options in the event of a crisis.

b. The strategic analysis should identify the core business lines of the institution as well as the critical functions, draw up their map according to the structure of the institution and allocation to the significant entities for its business. Thus, the recovery plan should include measures to reduce the institution's risk profile in order to be able to respond to liquidity shocks and consolidate its capital, as well as to describe strategic options (business line divestiture and debt restructuring). 
c. Significant changes since the last recovery plan represent a summary of major changes since the release of the previous recovery plan, including any significant events notifications or recovery plan updates.

d. The communication plan should aim at ensuring effective communication both in the internal environment and with the external environment on aspects related to the implementation of the recovery plan.

e. Preparatory measures should include an analysis of the preparatory measures which, in the pre-recovery phase, could contribute to increasing the effectiveness of the identified recovery options.

f. Recovery plan indicators represent one of the basic elements of the plan. For the purposes of recovery plans, "recovery plan indicators" mean qualitative and quantitative indicators established by each bank under the framework set out in these procedures to identify the steps in which the appropriate measures identified in the plan. Banks must include in the recovery plans at least the following categories of indicators:

- capital ratios;

- liquidity ratios;

- profitability indicators;

- asset quality indicators.

In addition, banks should include two other categories of indicators (market-based indicators and macroeconomic indicators) in the recovery plan, unless they provide satisfactory justifications to the National Bank, as these categories are not relevant to the legal structure, the risk profile, size and/or complexity of the bank. These indicators do not automatically trigger a specific recovery option but trigger an escalation process within the affected institution, which would involve determining the best way to address the crisis. The worsening of those indicators can be considered as an "early warning signal".

The other element of preparation stage represents the elaboration by National Bank of Moldova of the Resolution plan, for each licensed bank, which is carried out in a process of close cooperation between the NBM and the banks, in line with the provisions of the recovery plans, with the purpose of establishing viable mechanisms to ensure, if necessary, to remedy the situation of the bank or to liquidate it with a minimal impact on the national financial system and public resources.

\subsection{EARLY INTERVENTION}

At this stage, the NBM is authorized to take certain measures in respect of a bank if it violates (or is likely to breach) the regulatory requirements for banking activity. These measures relate mainly to requests addressed to the bank for undertaking several actions, such as replacing its governing bodies, implementing the arrangements foreseen in the recovery plan, developing debt restructuring negotiation plans, making changes to the business strategy, legal or operational structure of the bank. Taking into account the principle of proportionality, the Law provides for the competence of the National Bank to designate one or more temporary administrators of the bank when these measures prove to be insufficient to remedy the situation of the bank in accordance to Title III, Chapter I of the Law on bank recovery and resolution no. 232/2016. Provisions regarding the early intervention of the new law basically replace the old LIF provisions on the special administration regime.

\subsection{THE RESOLUTION}

Resolution involves the intervention of state authorities in a bank, in order to restructure it in order to achieve the objectives of the resolution. Thus, the objectives pursued by the National Bank in implementing resolution tools are to ensure the continuity of the commercial bank's critical functions; avoiding significant adverse effects on financial stability, in particular by preventing contagion, including market infrastructures and maintaining market discipline; protecting public funds by minimizing dependence on extraordinary public financial support; protect depositors covered by deposit guarantee legislation and protecting clients' funds and assets.

A resolution action may be ordered when the following conditions are cumulatively met:

a. it was determined by the National Bank of Moldova that the bank is entering or is likely to enter a state of major difficulty;

b. considering the available time and other relevant circumstances, there is no reasonable prospect that the state of major difficulty could be hindered in a reasonable period by alternative measures by the private 
sector, including measures taken by an institutional system protection, or by means of supervisory measures, including early intervention measures or measures to reduce or convert the relevant capital instruments made in relation to that bank;

c. the resolution action is necessary from the public interest point of view.

If a commercial bank meets all the resolution conditions, the NBM can apply a set of resolution tools, individually or in any combination, except for the asset separation instrument, which applies only in combination with another resolution instrument, to avoid any potential moral hazard. The Law on bank recovery and resolution does not expressly lay down the circumstances of the use of an instrument or another; however, when the resolution instruments are applied, the NBM takes into account the objectives of the resolution and chooses those instruments which allow the highest possible achievement of the objectives considered by it to be relevant to each situation.

The resolution tools that can be applied are:

- Sale of business involves the transfer by the NBM to a potential viable buyer of shares or other proprietary instruments issued, as well as the transfer of assets, rights or obligations of the bank;

- Bridge bank involves making similar transfers to a bank created to receive and hold some or all of the shares, assets, rights, and obligations of one or more banks subject to resolution. This is done in order to preserve the critical functions and the subsequent sale of the bank. The share capital of the bridge bank is wholly owned by the Ministry of Finance.
- Asset separation is materialized by transferring the assets, rights or obligations of a resolution bank or a bridge bank to an asset management vehicle. Such a vehicle is a legal entity created in order to receive and hold such assets, rights, and obligations, with a share capital wholly or partially owned by one or more public authorities.

- Bail-in - under this instrument, the National Bank has the power to reduce, even in full, the amount of the principal or the outstanding amount of the eligible debts of a bank subject to the resolution, the ability to convert the eligible debts of a bank subject to resolution into equity instruments, to cancel the debt instruments issued by a bank subject to the resolution and other similar powers, explicitly set out in the draft, aimed at recapitalizing the bank subject to the resolution on behalf of certain classes of creditors. It is important to underline that the application of resolution instruments does not require the consent of the bank's shareholders subject to the resolution or its creditors.

Resolution measures of banks will be funded from the bank resolution fund, thus avoiding the use of public budget resources. According to article 303 of the Law on bank recovery and resolution no. 232 of 03.10 .2016 , this fund will consist of the collected contributions from the banking sector, the volume of which should be constituted by 31 December 2024 - 3\% of the volume of guaranteed deposits of banks. The bank resolution fund will be managed by the Deposit Guarantee Fund in the banking system, and the use of resources will be made only based on the decision of the NBM.

Table 1 Internal recapitalization vs. use of public money or bankruptcy

\begin{tabular}{|c|c|c|c|}
\hline \multirow{2}{*}{$\begin{array}{l}\text { Consequences resulting from } \\
\text { the actions taken }\end{array}$} & \multicolumn{3}{|c|}{ Ways to recover the situation of a bank } \\
\hline & Bankruptcy & $\begin{array}{l}\text { External recapitalization } \\
\text { (use of public money) }\end{array}$ & $\begin{array}{c}\text { Internal recapitalization } \\
\text { (creditors support the loss) }\end{array}$ \\
\hline $\begin{array}{l}\text { Continuing the vital functions } \\
\text { of the bank }\end{array}$ & NO & YES & YES \\
\hline Financial stability is maintained & $\begin{array}{c}\mathrm{NO} \\
\text { (in a case of a systemic } \\
\text { important bank) }\end{array}$ & YES & YES \\
\hline $\begin{array}{l}\text { A taxpayer is exempted from } \\
\text { incurring costs }\end{array}$ & YES & NO & YES \\
\hline $\begin{array}{l}\text { Guaranteed deposits are kept } \\
\text { secure }\end{array}$ & YES & YES & YES \\
\hline $\begin{array}{l}\text { Unguaranteed deposits are } \\
\text { kept secure }\end{array}$ & NO & YES & NO \\
\hline
\end{tabular}


The table 1 presents three options of a bank's recovering.

Each solution chosen to recover the bank implies certain consequences, namely:

- Under the assumption of bankruptcy, all clients and partners of the bank are affected by borrowers, creditors, and payment service users. The only categories that are less affected are the holders of guaranteed deposits and the bonds guaranteed by certain types of contracts with adequate protection. It should be mentioned that there will be no direct cost for the taxpayer, and financial stability will be affected in those situations where the bank in bankruptcy is of systemic importance.

- In the case of external recapitalization - called bail-out, this procedure will ensure the continuity of the vital functions of the bank (cards, current accounts, etc.) and the stability of the current financing of the companies. Guaranteed deposits will remain secured, covered by the guarantee mechanism, and covered bonds will be legally covered within the warranty coverage. Regarding unsecured deposits and other unsecured claims (shares, bonds, etc.), the decision belongs to the one that covers the costs of public resources, namely the Government. Instead, the cost is to be supported by the taxpayer by covering recapitalization costs.

- The internal recapitalization - the bail-in process, will ensure the continuity of the bank's critical functions (payment systems, cards, current accounts, etc.) and the stability of the company's current funding. Guaranteed deposits will remain secured, covered by the guarantee mechanism, and covered bonds will be legally covered within the warranty coverage. With regard to unsecured deposits and other unsecured claims (bonds, etc.), they will be managed by the resolution authority in order to recover the money for recapitalization. Instead, there will be no costs incurred by the taxpayer.

If the National Bank withdraws the license of one bank, there is the Deposit Guarantee Fund in the Banking System (FGDSB) to protect the population's money deposits. The primary purpose of this fund is to prevent "panic" among depositors and, as a result, avoid massive withdrawal of deposits. The domestic Deposit Guarantee Scheme has been in operation since 1 July 2004 and is managed by FGDSB, which is incorporated as a legal entity governed by public law. This gives legal independence to the respective body, which means avoiding political influence in the decision-making process, the banking industry, etc. At the same time, the Deposit Guarantee Scheme in Moldova implies the mandatory participation of all banks in the republic and is reflected in the majority of deposits in national currency and in foreign currency held by resident and non-resident individuals in the respective banks.

From 1 January 2018, based on the Law no. 30 of 24.03.2017, the guaranteed maximum in the Republic of Moldova is 20,000 lei, covering the largest share of small deposits while avoiding the overcoming of the financing capacity of the banks in the system. The funds of the Deposit Guarantee Fund in the Republic of Moldova that can be used for the repayment of the guaranteed deposits are accumulated from the initial and quarterly contributions made by the licensed banks.

This Deposit Guarantee Scheme does not solve banking market problems and does not in any way assure the stability of the financial-banking system, but it is just another component that complements the legal framework of insurance and maintenance of a stable and robust banking system. The efficient work of this Fund can ensure the credibility of the banking system, as well as reduce the expenses of banks and the state in case of need for intervention in times of crisis.

\section{CONCLUSIONS}

For the anticipation of bank failures in the Republic of Moldova, the following recommendations would be appropriate:

- development of flexible macro-prudential policies in response to the emergence of systemic risk;

- regular review of the adequacy of the macroprudential regulatory framework with the purpose of its adjusting to the relevant economic scenarios and systemic risk mitigation to ensure the stability of the domestic banking system; 
- due to the importance of ensuring the stability of the domestic banking system, it is strictly necessary to resume the activity of the National Committee for Financial Stability in a revised composition;

- application of differentiated supervision of systemically important banks, which will allow applying tougher prudential rules, with respect to the "large" exposure limits, the current and long-term minimum liquidity level, the riskweighted capital adequacy ratio;

calculating and requiring systemically important banks to maintain additional capital buffers in order to cope with systemic risks.

\section{WORKS CITED}

Law on Banks and Banking Activity: no. 601. (1991, June 12). Official Monitor of the Republic of Moldova, 006.

Law on Financial Institutions: no. 550-XIII of 21.07.1995. (1996, January 01). Official Monitor of the Republic of Moldova

Law on payment services and electronic money, in force on the expiration of one year from the date of its publication: no. 114 of 18.05.2012. (September 14, 2012). Official Monitor of the Republic of Moldova, 193-197/661.

Law on insolvency: no. 149 (March 13, 2006). Official Monitor of the Republic of Moldova, 193-197.

Law on bank recovery and resolution: no. 232. (October 04, 2016). Official Monitor of the Republic of Moldova

Law for amending Art. 6 of the Law no. 575/2003 on guaranteeing the deposits of individuals in the banking system: no. 39. (March 24, 2017). Official Monitor of the Republic of Moldova, 109-118.

Regulation on the use of e-banking systems: no.376 of 15.12.2005. (January 6, 2006). Official Monitor

Received for publication: $\quad 28.03 .2019$

Revision received: $\quad 19.05 .2019$

Accepted for publication: $\quad$ 10.07.2019

\section{How to cite this article?}

Style - APA Sixth Edition:

Ciobu, S., Iordachi, V., \& Jalba, A. (2019, July 15). Anticipation of Bank Failures in The Republic of Moldova. (Z. Čekerevac, Ed.) MEST Journal, 7(2), 21-30. doi:10.12709/mest.07.07.02.03

Style - Chicago Sixteenth Edition:

Ciobu, Stela, Victoria Iordachi, and Andrei Jalba. 2019. "Anticipation of Bank Failures in The Republic of Moldova." Edited by Zoran Čekerevac. MEST Journal (MESTE) 7 (2): 21-30. doi:10.12709/mest.07.07.02.03.

Style - GOST Name Sort:

Ciobu Stela, Iordachi Victoria and Jalba Andrei Anticipation of Bank Failures in The Republic of Moldova [Journal] // MEST Journal / ed. Čekerevac Zoran. - Belgrade - Toronto : MESTE, July 15, 2019. - 2 : Vol. 7. - pp. 21-30.

Style - Harvard Anglia:

Ciobu, S., Iordachi, V. \& Jalba, A., 2019. Anticipation of Bank Failures in The Republic of Moldova. MEST Journal, 15 July, 7(2), pp. 21-30.

Style - ISO 690 Numerical Reference:

Anticipation of Bank Failures in The Republic of Moldova. Ciobu, Stela, lordachi, Victoria and Jalba, Andrei. [ed.] Zoran Čekerevac. 2, Belgrade - Toronto : MESTE, July 15, 2019, MEST Journal, Vol. 7, pp. 21-30. 